\title{
The Preference of Choosing Non-Political Party Organization in the Election (Case Study: Teman Ahok Members to Jakarta 2017 Regional Head Election)
}

\author{
Nurul Khansa Fauziyah, S.Sos. \\ Magister of Sociology, Universitas Indonesia \\ khansaplast@gmail.com
}

\begin{abstract}
The results of this study reveal the reasons behind the preference of people to campaign through non political-party organizations, as well as the processes and consideration of their thought to maximize the resources they have in the elections. The findings can provide knowledge to the reader that there are alternative campaigns that are not at all based on political parties. These findings will become an evaluation material for political parties to find out what steps needed to improve their performance.

This research takes the case of a supporting organization, Teman Ahok, who seeks to nominate Basuki Tjahja Purnama (Ahok) independently in DKI Jakarta Governor election on 2017. The purpose of this research is to know the "thinking process" of the members of Teman Ahok until finally founding / joining this non political-party organization to nominate Ahok for governor. The main argument of this research is, Teman Ahok's members realize, to achieve their goal making Ahok as Governor without political-party pressure, they must strive to nominate Ahok through independent path. The limits of political power they have, force Teman Ahok to make a strategy of establishing a complex and massive organization to garner public support. All the decisions they choose are determined by the information they have and processed with careful consideration.
\end{abstract}

Using qualitative-descriptive approach and case study methods, I did deep interview with 3 founders of Teman Ahok and 3 members of Teman Ahok. Secondary data was taken from previous research, mass media, and related websites. The Rational Choice Theory of Friedman and Hechter will be used to uncover the "thinking process" of the actors in achieving their goals, their considerations, the effects, as well as how they minimize the obstacles they face in achieving their goals.

Keywords: Organization; Non-political party; Rational choice

\section{Introduction}

Since then people can choose themselves who is the head of their region. Direct elections can directly support the continuation of local political democratization (Choi, 2007). The new condition rated by Vel that - it created a shift in the orientation of the winning strategy of prospective head region. If the original campaign was carried out to foster public confidence and to garner support, but it is different now, the target of the campaign is to collect voice or vote (Vel, 2005). During the passage of Law No. 23 of 2004, the function of political party 
recruiting the candidates for regional heads is often regarded as an instant pattern for heading the election. In every election the political party only published that they had open the registration, and that was all. There is no guarantee that leaders nominated have good political knowledge.

Then there were dissatisfaction from various parties. So that in 2007, the Constitutional Court revised Article 59 paragraph 1 of Law No. 23 of 2004 on Regional Government that allows independent candidates, peoples who are not nominated by political parties will be able to submit themselves or submitted become candidates for regional head election. The foundation is Article 18 paragraph 4 of the 1945 Constitution of the Republic of Indonesia which states that "Governors, Regents and Mayors respectively as heads of provincial, district and municipal governments are elected democratically". Plus Article 27 paragraph 1 and Article 28D of the UUD 1945. (Alfons in Martini dan Ibrahim, 2014) Specifically, in 2007 the Constitutional Court also granted judicial review on Law Number 32 Year 2004 regarding Regional Government by issuing the decision of the Constitutional Court Number 5 / PUU-V / 2007 to cancel Article 59 paragraph 1 of Law Number 32 Year 2004 which states that the election of regional head and deputy head of region is a candidate pair proposed simultaneously by political parties or a coalition of political parties. Then, after the Decision of the Constitutional Court No. 5 / PUU-V / 2007, independent candidates shall be further stipulated in Law Number 12 Year 2008 concerning the Second Amendment of Law Number 32 Year 2004 regarding Regional Government precisely in Article 59 paragraph 1 stating that "the election of regional head and deputy regional head are: (a) the candidate proposed by a political party or coalition of political parties and (b) the candidate supported by a number of persons ".

In Law Number 8 Year 2015 there is a regulation for head regions without parties, where people can be a candidate without recruited by political party. The total votes required in this law are $6.5 \%, 7.5 \%, 8.5 \%$, and $10 \%$ of the total population per cluster. To become the Governor of DKI Jakarta, with 6,996,951 inhabitants of populations, the obligation of candidates for governor is listed in Article 41 No. 1 point C of Law No. 8 of 2015 on Amendment to Law Number 1 Year 2015 On Stipulation of Regulation Government in lieu of Law Number 1 Year 2014 on the Election of Governors, Regents, and Mayors Became Law, which written;

"An individual candidate may register as a Candidate of Governor and Candidate of the Vice Governor if it meets the terms of support with the provisions ... The province with a population of more than 6,000,000 (six million) to 12,000,000 (twelve million) people shall be supported at least 7,5\% (seven and a half percent). "

According to some circles, the requirement to become an independent regional head candidate is still quite hard. Therefore, to enroll candidates must submit copies of identity cards (KTP) and support statements. Then the Regional General Election Commission (KPUD) must perform inspection of the conditions that have been attached by the candidate of the regional head and his / her deputy candidate. In the Regulation of the General Election Commission Number 9 Year 2015 Article 16, it is explained that the research on the individual candidate support documents consists of two stages, administrative check and factual check.

However, until 2017, at least there have been 25 couples of regional heads - from different regions in Indonesia - who won the election of regional head candidates from independent way. According to Skala Survei Indonesia (SSI), $14.4 \%$ of the candidates for 
regional heads from independent channels won the election. There are $35 \%$ of candidates for independent heads of regions in Indonesia. $77.8 \%$ are in areas with a Permanent Voters List (DPT) below 500,000. But the rest are in areas with a large number of DPT.

This research's objectives are (1) to know why do Teman Ahok formers and members prefer non-political organizations to support Ahok as a candidate for governor, (2) to understand how is the rational thinking-process of the former of Teman Ahok to decide to establish a nonpolitical party organization, (3) to know what are the things they considerate so that they can support Ahok through independent way.

Researcher want to see sociologically that Teman Ahok's members are actors that had intent and purpose of their choice to support Ahok through independent ways with non-party political organizations. The limit of their power as civil society against the domination of political parties, as well as Ahok's condition that was hit by SARA issues, became a challenge for them in achieving the goal. According to Friederich and Hecter, people will acting rationally. When acting rationally, individuals doing a careful calculations to maximize the profits. The calculation is in the form of a large-sized prejudice of a preference. They must choose an action that can give the best results according to their own consideration. That action is a purposive action that will producing social impact. In the process of mature thinking, the actors are considered to have a good knowledge. At the end, authors will look at their organizations' actions and networks to find out what action products they achieved.

\section{Literature review}

Amitai Etzioni, since 1982 has been seriously concerned with the development of this type of organization. His view was on the problems of modern organization at that time. The emphasis sits on the understanding that the organization is a social unit that seeks to pursue multiple goals in certain social circumstances. There are factors that affect the goals of the organization, and mostly through a process of struggle. The struggle in this case is not against something that is outside the organization alone, but the toughest challenge comes from within the organization itself. The effectiveness of organiasation is measured by how good it achieves its objectives, while its efficiency is measured by how many resources are used to produce an input unit that is closely related to organizational goals. (Etzioni, 1982)

According to Friedman and Hechter (2008), humans will usually assume that the actions they did since they were born are controlled by his family and school; law and ordination; company policy; churches, synagogues and mosques; and hospitals and burial chambers. By limiting the feasibility of actions that individuals can take, applicable game rulesincluding norms, laws, agendas, and voting rules-systematically affect social products. Friedman and Hechter describe two other ideas they regard as the basis for rational choice theory. The first is the aggregation mechanism, or process when "individual actions are combined to produce social impact". The second is the importance of information in determining rational choice.

This theory is one of the classes of purposive action models that can be found in all social sciences. Social actors are called purposif when in action, they intend to produce certain results. The basic argument put forward by rational choice theory, a metatheoretic assumption rather than an empirical generalization, is that society acts rationally. A typical rational element is his idea of optimization: in acting rationally, individuals do the optimization, by maximizing 
profits or charging expenses, when they have to choose a series of actions to take. Social actors will choose actions that can deliver the best results according to their own consideration. In particular, social actors try to control the sources in which they have an interest. The main purpose of this theory is to explain the behavior of social systems, both in small and large scales, rather than individual behavior.

There are some story about the struggle of the supporting group for regional head candidates since the first election was held. The support group of presidential candidate Joko Widodo allied in BARA JP (Barisan Relawan Jokowi Presiden). Melia Halim found this group did various efforts for one purpose, to successing Joko Widodo won the 2014 presidential election of Indonesia. The factors that made the fandom group (fan loyalty) is doing an activity (fan activism) moves massively and exerts considerable influence on the popularity of the candidate (Halim, 2014).

Based on the above description, it appears that the nomination of regional heads independently has already existed in several regions in Indonesia. Whether independent candidates or not, they have a supporting team.

\section{Research method}

This research has been done on November 2017 until February 2018 in DKI Jakarta, Indonesia. This research used qualitative approach with a case study method, using a wide variety of information sources in data collection to provide a deep and detailed understanding of the organization in this study. As explained by Cresswell, the qualitative method is an attempt to understand the system of meaning or knowledge possessed by the research informant. The system of meaning influences the informant in addressing and establishing his social relations. Then author can find out the relationship style that was built among the actors. Therefore, the authors approach in the form of in-depth interviews of actors who are considered to have the competence to provide information. (Creswell, 1994)

However, secondary data is still required to obtain past information. This research goes through several stages, starting from searching for initial information about Teman Ahok from his official website, then conducting in-depth interviews to Teman Ahok's formers and members, up to whose have other information about the formation of Teman Ahok. After getting a lot of information, then the authors will interpret the data that has been interconnected, so we can drawn the conclusions.

\section{Discussion}

In this case Teman Ahok comes as a civilian who wants Ahok eligible to become an independent governor candidate in the 2017 regional head election. One of the most popular reasons in the mass media is that Ahok has not been supported by any party yet, he has problems with the DKI Jakarta Regional Representative Council (DPRD) about the 2015 Regional Budget. (Tempo magazine, 26 June 2016 edition) Ahok's political position was quite vulnerable, so he needs alternative political way. Members of Teman Ahok form a large enough network of organizations and move massively, so they were succesfully collected more than one million copies of KTP and the supporting form from the citizens of Jakarta Special Capital Region (DKI). The organization was formed by five young people from various backgrounds. Then recruit more people and give them a significant and systematic task. They invite the 
residents of Jakarta to provide support KTP for Ahok as independent candidate. It describes if Ahok become a governor by independent way, he could focus on working for Jakarta without political party intervention. This alternative way from Teman Ahok gives a significant social impact. Proven with many people who gave their support through Teman Ahok. This condition indicates the existence of an advantage achieved by the members of Teman Ahok over the negative message about political party.

The requirements set for candidate couple of regional heads who wish to volunteer through independent way are difficult. The number of DPT in DKI Jakarta area in Pemilukada 2012 are 6,996,951 people. If it refers to the latest law on Pemilukada, namely Law Number 8 Year 2015, Ahok must collect at least 7.5\% (Seven point five percent) of votes or about 525,000 the number of copies of ID cards and support statements. This requirement is a key requirement. If he can unable fulfill the requirement, he will fail to become an independent candidate.

The main argument in this study is that some civilians realize that the limitations of their political power must be overcome by using alternative ways that may still be used to nominate someone who is considered good for them to become head of the region. In this case, to achieve their goal of making Ahok a Governor free from the pressure of political parties, Teman Ahok attempts to independently use alternative pathways.

\section{Teman Ahok and its network}

Teman Ahok is a political volunteer organization. Formed in February 2015 by five youths aged 23-25; Amalia Ayuningtyas, Muhammad Fathony, Aditya Yogi Prabowo, Richard Hadris and Singgih Widiyastono. They are also the former or Jakarta Baru volunteers who was support Joko Widodo and Basuki Tjahja Purnama in the Election of DKI Jakarta 2012. Then they meet again in Begal APBD action in Bunderan Hotel Indonesia. At that moment they made the association of Teman Ahok on the grounds that Ahok did not have a favorable condition and had not been proposed by a political party. Based on information from the Tempo.co online page, Teman Ahok has been legalized by notarial deed dated June 16, 2015. The division of duties is, Amalia and Singgih served as spokespersons, they are always present in the interview and question and answer session, including in Mass media. While the other three, had the behind the scenes works. Yogi took care of the booth and volunteer posts, Fathony took care of the logistics department such as the provision of machandise and basic member needs, while Richard was in charge of ensuring the support data goes well.

The author conducted a very long interview with the 3 formers of Teman Ahok and 3 other members of Teman Ahok. They were explained in detail the division of works and the networks of the organizations from the inner until outer circle of whose met directly with the supporters. Structurally, Teman Ahok has four teams. The first team called "Tim Darat", because this team was working mobile in various places, face to face with the volunteers, then divided again into Posko Partisipasi, Posko Binaan, and Booth Mall. Posko Partisipasi is a post of people who have the initiative to mobilize personal support. The members are about 35 people. Then the forms and copies of collected KTPs are given to the Landline coordinator. Posko Binaan is a post that spread in each districts throughout Jakarta. The number of coordinators are quite a lot, which is 150 people. While Booth mall is a post that spreaded in the malls that will provide a form for the mall visitors who want to support. There are also 
some marchandise sold. The number of malls reached 30 malls in several areas of Jakarta. But it has different openings and caps. Each mall has 4-8 booth guards.

The next team is the Digital team, this team worked in the virtual domain (internet). The Digital Team was divided into website managers, group managers and fanpages, official account line managers, Whatsapp complaints administrators, and admin monitoring - graphic design. Social media they used are Twitter, Facebook, Instagram, and Website. Everyday Teman Ahok provide reports on the amount of support and money that already collected from the sale of machandise. Any information of Teman Ahok can be seen through the social media that they managed, including the effort to handle the issue that hit Ahok. They confirmed every wrong issue through social media. Then the third one is Logistics team, this team took care of the entry and exit of the goods they sell to the supporters of Ahok. The team works with the Land Team (Tim Darat) in terms of logistics distribution, so they focus on the data of available goods. The number of logistics team members is only 5 people.

The last one is the Data Entry team, the job of this team was look after the ID card support. They also verify incoming data to avoid double-data existence. Stages done by this team was, when the post and booth has finished collecting data in one day, the data submitted to the data input coordinator. Then the data is manually verified by the team and assisted by additional members who are willing to help. Then the data is entered using a computer that is already available, and reported to the Digital team for publication.

They said that the network they have is people who have relatives and no recruitment for the general public. The connections have been built since they actively volunteered for Jakarta Baru (2012) and Jokowi - JK volunteers in the presidential election (2014). The support they received came from the relationships they built on previous volunteer activities. Including Hasan Nasbi who is the leader of the state funding movement in Bunderan HI Jakarta.

About the reasons why they choose to support Ahok by independent way, I have interviewed 3 formers (Richad, Yogi, and Singgih) and 3 members of Teman Ahok (Hana, Nofri, and an unpublished admin of Teman Ahok's social media account). Their answers are, (1) Because we support Ahok and want him leading Jakarta again without depending on political party, (2) by independent way it will minimalize the chance of political dowry, (3) so far, there has been no convincing party to support, (4) this is our way to use alternative method of supporting and campaigning in political election, (5) because at that time Ahok hits by SARA issue and has problem with DPRD so we have to start to collecting support for Ahok governor.

\section{Analysis}

In this case Teman Ahok becomes the focus as the actors in rational choice theory. Actors are seen as having a purpose and purpose for their actions. Teman Ahok was founded as a new alternative in campaigning. The actors in Teman Ahok are considered had the hierarchy-ofpreferences whose considering two obstacles to their actions. First, is the scarcity of resources. In this case, the Teman Ahok is consist of young people who have weak political base to support Ahok as a candidate for governor. On the other hand, there are a very strong power of political parties that can easily carry Ahok forward as a candidate for governor. So, the resource that is considered that limited in this case is Political Power. Because of their weak political power, the formers of Teman Ahok decided to create a support organization that wanted to 
carry Ahok through an independent path. They hope, they can unite become a big and strong political power that can compete with political parties.

The second obstacle for the actor in Hecter's theory, social institution, was not so noticeable by Teman Ahok's members. Instead they have social institutions background that support them to form this organization. The former of Teman Ahok were joined the supporting group of Joko Widodo when he was running for governor in 2012 and for president in 2014. So, the social institutions in this case do not become obstacles but support them to establishing Teman Ahok.

According to Friedman and Hecter, actor considered had enough information to choose one from a lot of choices. The quality and quantity of the information affects the choice of the actor. In this case, Teman Ahok was considered to have enough information about the performance of the party and also Ahok's political condition. They saw unconformity between Ahok's integrity and the character of political parties in Indonesia. Then they thought of making a non-mainstream way of collecting support from Jakarta citizens as much as possible to make Ahok an independent governor candidate. Their experience in various political activities and campaigns provided them with a wealth of information about electoral matters.

\section{Conclusion}

After watched the performance of political party and political condition of Basuki Tjahja Purnama itself, five former members of New Jakarta and Jokowi-JK decided to established Teman Ahok, a non-political organization determined to carried Ahok as a candidate for governor of DKI Jakarta through independent way. After considered their political power that far below the political party power, they decided to formed Teman Ahok. Teman Ahok wants Ahok being a Governor candidate by independent way it to minimalize the chance of political dowry with the political party. This action is a criticism for the political party that perceived poor performance in recruiting candidates for regional heads. Political parties are also perceived to always asking for reciprocal behind their support for the candidates. This condition becomes an introspection that needs to be considered and we have to looking for the solution, in order to balance the people's preference for political parties and non-political party organizations. Even expected that both can work together with the community to build a better political environment.

\section{References}

1945 Constitution of the Republic of Indonesia

Choi N. (2007). Elections, parties, and elites in Indonesia's local politics. South East Asia Research, 15, 325-354.

Creswell JW. (1994). Research design qualitative and quantitative approaches. Nebraska: Sage Publication

Constitutional Court Number 5 / PUU-V / 2007.

Etzioni, Amitai. (1985). Organisasi-organisasi modern. Jakarta: UI-Press

Halim M. (2014). Fandom and fan activism in politics understanding barisan relawan Jokowi presiden 2014. Thesis University of Indonesia

Law Number 8 Year 2015 about choosing Governor and Mayor.

Law No. 23 of 2004 on Regional Government 
Martini NPE \& Ibrahim R. (2013). Problematika calon independen dalam pemilihan umum kepala daerah. Kertha Semaya, 01, 3.

Vel, Jacqueline. (2005). Pilkada in East Sumba: An old rivalry in a new democratic setting. Indonesia. Southeast Asia Program Publications at Cornell University, 80, 81-107.

Ritzer, George. \& Douglas J. Goodman. (2008). Teori sosiologi: Dari teori sosiologi klasik sampai perkembangan mutakhir teori sosial postmodern. Bantul: Kreasi Wacana.

Skala Survei Indonesia (2016, February 2). Suramnya Masa Depan Calon Independen dalam Pilkada. Retrieved from www.skalasurveiindonesia.com/suramnya-masa-depan-calonindependen-dalam-pilkada/ 